ception of an object not actually present, involving the recognition of its absence, an illusion is the subjective perception of an object actually present, but in charncters which the object doe's not really possess. With appropriate alterations these definitions will cover the abstract hallucination and phantastic illusion of Wundt as well.

In his second chapter, the author ably, but we believe unsuccessfully, endeavors to defend his refusal to recognize the distinction between illusion and hallucination as the leading principle of classification, though he admits the necessity of making this distinction in accorlance with the leading alienists. Wundt, an authority whose teachings in pischological physiology the author of the present volume has most successfully assimilated, hats drawn attention to the numerous connecting links existing hetween illusions and hallucinations, and get strongly insintson utilixing their general differences as a hasis of classification. We find the chice drawbinte to the oflherwise great value of the work, in its fialure to give ade puitte spatec to the anatomical mechanism concerned in false registrations of the perceptional and conceptional sphere. If it be borne in mind that while even hallucinations may be based on actual impressions, the latter are not the determining factor of the hallucination, the difficulty in discriminating between these perversions is overcome; this is illustrated by the occasional persistence of dream-images in the waking state, and the moving of certain hallucinated imagres consonant with the movements of the eye-ball. If an actual or subjective impression, say in the shape of chermutepsia and timnitus, be granted to exist in a subject hallucinating the vision and voice of the Virgin Mary, it will be instantly recognized ly erery observant alienist, that the real determining factor is here centrifugal, while in the illusion, which constructs, out of a ball rolling in an ill-lighted apartment, a mouse, the determining factor takes a centripetal course. In the former instance, the misinterpretation lies ready made in the Cortex, and seizes on the slight external pretext, whose existence we only admit for the sake of the argument, to incorporate it, in its substance ; in the latter, it is based upon an imperfect registration and a gradual constructive interpreting process. Nothing could more forcibly illustrate the correctness of these propositions than the very case cited from Wundt by Mr. Sully of a forester who saw the real objects of the outer world, (furniture and tapestry, for example,) through the wood piles which formed the subjects of his hallucinations.

With these remarks on the propositions of the opening chapters, our criticism ceases to be adverse. In the last twelve chapters of the book, the author gives a concise review of the chief theories held by alienists and metaphysicians on the perceptional illusion, the introspective illusion, dreams illusions of memory, and these of belicf. We refrain from again pointing out places where the author encroaches on the fields of delusion and hallucination, as he has given a wider scope to his definition of the illusion, than we are inclined to consider proper. It is but just to say that he gives a just interpretation to the views of alienists, an interpretation which only occasionally manifests that tincture of uncertainty which is unavoidable on the part of one devoid of a practical knowledge of the insane.

The perusal of this work cannot fail to be profitable to the stulent of mental patholengy as well as of metaphysics. More reliable in the latter fickl, than in the former, it is yet it sucressful attemptto present the modern (ierman ideals on the subject, and to combine the teardhings of the pratetical and the alsotrate pingeloul. ogists. To the general reater we cam only repeatt, whit we sitid at the outset, it is the clearest remlition of a diflicult jet fatscinating theme, to be found in our language.

E. C. Siltzka, M. I).

ON THE DISCOVERIES OF THE PAST HALFCENTURY RELATING TO ANIMAL MOTION.

By J. BURHON-S.INDERSUN, M.D., LL.D., F.K.S.

The two great branches of Biology with which we concern ourselves in this section, Inimal Morphology and Physiology, are most intimately related to each other. This arises from their having one subject of study-the living animal organism. The difference between them lies in this, that whereas the studies of the anatomist lead him to fix his attention on the organism itself, to us physiologists it, and the organs of which it is made up, serve only as i'estigria, by means of which we investigate the vital processes of which they are alike the ciuses and consequences.

To illustrate this I will tirst ask you to imagine for a moment that you have before jou one of those melancholy remainders of what was once an animal-to wit. a rabbit-which one sees exposed in the shop of poulterers. We have no hesitation in recognising that remainder as being in a certain sense a rabbit ; but it is a very miserable vestige of what was a few days ago enjoying life in some wood or warren, or more likely on the sand-hills near Ostend. We may call it a rabbit if we like, but it is only a remainder-not the thing itselt.

The anatomical preparation which I have in imagination placed betore jou, although it has lost its inside and its outside, its integument and its viscera, still retains the parts for which the rest existed The final cause of an animal, whether human or other, is muscular action, because it is by means of its muscles that it maintains its external relations. It is by our muscles exclusively that we act on each other. The articulate sounds by which $1 \mathrm{am}$ addressing you are but the results of complicated combinaticns of muscular contractions - and so are the scarcely appreciable changes in your countenances by which I am able to judge how much, or how little, what I am saying interests you.

Consequently the main problems of physiology relate to muscular action, or as I have called it, animal motion. They may be divided into two-namely (1) in what does muscular action consist-that is, what is the process of 
which it is the effect or outcome? And (2) how are the motions of our bodies co-ordinated or regulated? It is unnecessary to occupy time in showing that, excluding those higher intellectual processes which, as they leave no eraceable marks behind them, are bejond the reach of our methods of investignation, these two questions comprise all olhers concerning animal motion. I will therefore proceed at once to the first of them-that of the process of muscular contratction.

The yeitrs which immedialtely followed the origin of the British Association exceceded any earlice period of equal length in the number and importance of the new fatts in m: rphology and physiology which were brought (1) light; for it was during that period that Johannes Miller, Schwann, Ilenle, and, in this country, Sharpey, Bowman, and Marshall Hall, accomplished their productive labors. But it was introductory to a much greater epoch. It would give you a true idea of the nature of the great advance which took place about the midelle of this century if I were to define it as the epoch of the death of "vitalism." Before that time, even the greatest biologist $-c . s^{\prime} \mathrm{J}$. Nitller-recognized that the knowledgre they possessed, buth of vital and physical phenomena, wis insufficient to refer both to a common measure. The method, therefore, was to study the process of life in relation to tach other only. Since that time it has becone fundamental in our science not to regard any rital process as understcod at all, unless it can be brought into relation with physical stindards, and the methods of physiology have been based exclusively on this principle. l.et us infuire for a moment what cillses halle conduced to the chatnge.

The most eflicient cause was the progress which had heen male in physics and chemistry, and particularly those incestigations which led to the establishment of the doctrine of the Conservation of Energy. In the application of this great principle to physiology, the men to whom we are indebted are, first and foremost, J. R. Mayer, of whom I shall say more immediately; and secondly to the great physiologists still living and working among us, who wete the pupils of J. Maller-viz.; Helmholte. Ludwigr, bu Bois-Resmond, and Brilicke.

As regatrols the subject which is tirst to occupy our altention, that of the prociss of muscular contriction, J. R. Iluer ocsupies so leadung a position that a lange proportion of the researches which have been done since the new eri, which he had so important a share in establishing, may be rightly considered as the working out of principles enunciated in his treatise' on the relation between organic motion and exchange of material. The most important of these were, as expressed in his own words: (1) "That the chemical force contained in the ingested food and in the inhaled oxjgen is the source of the motion and heat which are the two products of animal lite: and (2) that these products vary in amount with the chemical process which produces them." Whatever may $b$ : the claims of Mayer to be regarded as a great discovery in physics, there can he no doubt, that as a physiologist, he deserves the highest place that we can give him, for at a time when the notion of the correlation of different modes of motion was as yet very unfamiliar to the physicist, he boldly applied it to the phenomena of animal life, and thus re-united physiology with natural philosuphy, from which it had been rightly, because unavoidably, severed by the vitalists of an earlier period.

l.et me first endeavor shortly to explain how Majer himself applied the principle just enunciated, and then how it has been developed experimentally since his time.

The fundamental notion is this: the animal body resembles, as regards the work it does anil the heat it produces, a steam-engine in which fucl is continually being used on the one hand, and work is being done and heat

1 J. K. Majer. "Wie organiwhe liewegung in ihrem, Zusammen-

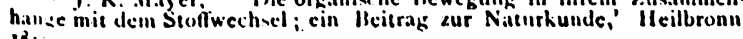
$1 b_{1}$, . produced on the other. The using of fuel is the chemical process, which in the animal body, as in the steam engine, is a process of oxitation. Heat and work are the useful products, for as, in the higher animals, the body cill only work at a constant temperature of about $100^{\circ}$ F., hesit may be so regiadel.

ilating previously determined the healt and work severally proclucible by the combustion of a given weighe of cillon, from his own experiments and from those of

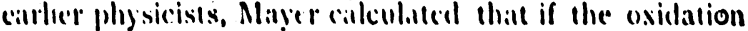
of earbon is asisumed to represent ipproximaltely the oxidation process of the bodly, the guantity of carbon actually burnt in a diay is far more than sulficient to account for the day's work, and that of the material expended in the body not more than one-fifth was used in the doing of work, the remaining four-titths being partly used, partly wasted in heat production.

Hating thus shown that the principles of the correlation of process and product hold good, so far as its truth could then be tested, as regards the whole organism, Majer proceeded to inquire into its applicability to the particul ir organ whose tunction it is "to transfurm chemical difference into mechanical effect "- nameIf muscle. Ilthough, he said, a muscles acts under the direction of the will, it does not derive its power of acting from the will, any more than a steamboat derives its power of motion from the helmsman. Again tand this was of more importance, at being more directly opposed to the previalent vititism), a muscle, like the steamboats use in the doing of work, not the material of its own structure, or mechamism, but the luel $-i$. 6 , the nutriment - which it derives diredly firom lle blood which tlows through its capillaties. "The muscle is the instrument by which the iransformation of force is accomplished, not the material which is itself transtormed." "This principle he exemplified in several wilys, showing that if the muscles of our bodies worked, as was formerly supposed, at the expense of their own substance, their whole material would be used up in a few weeks, and that in the case of the heart, a muscle which works at a much greater ratte than any other, it would be expencled in as many days-a result which necessarily involved the absurd hypoihesis that the muscular tibres of our hearts are so frequently disintegrated and reintegratted that we get new. he.uls onces a weet.

(In such considerations Majer founded the prevision. that, as soon as experimental mechods should become sufficiently perfect to render it possible to determine with precision the limits of the chemical process, either in the whole animal body or in a single: muscle, during a given period, and to measure the production of heat and the work done during the sime period, the result would show a quantitative correlation iretween them.

li the time at our disposill permitted. I should like to give a short account of the succession of laborious inVestirations by which these previsions have been verified. Begun by Bidrler and Schmidt in $1 S ; 1,{ }^{1}$ continued by Pettenkofer and Voit, ${ }^{2}$ and by the agricultural physiologrists $^{3}$ with reference to herbivora, they are not by any means completed. I must content myself with saying that by these experiments the first and second parts of this great subject-namely, the limits of the chemical process of animal life and its relation to animal motion under different conditions-have been satisfactorily worked out, but that the quantita'ive relations of heat production are as jet only insufficiently determined.

Let me sum up in as few words as possible how far what we have now learnt by experiment justifies Mayer's anticipations, and how it falls short of or exceeds them. First of all, we are

1 Midder and Schmidt, "I Die Verdauungrsïfte t.nd der Stoffwechsel," Leipriti, 1852.

2 Pettenkofer and Vuit, Zcitsı/hr. f. biolisid, passim, 1816-80.

- llenneberg and Stohmunn, "Beitrlige aur Begullndung einer ratiorellen fulterung der Wiedeiklluer," Hiunswick and (iüttingen, isco-ge. 
as certain as of any physical fact that the animal body in doing work does not usc its own muterial- that, as Majer says, the oil to his lamp of life is foud: but in addition to this we know what he is unaware of, that what is used is not only not the living protoplatsm itseli, but is a kind of material which wi.lely differs from it in chemical properties. In what may be cilled commercial physiology -i.c., in the literature of tratle pufts--one still meets with the assumption that the material basis of muscular motion is nitrogenous; but by many methols of prof it has been shown that the true "()el in der Flamme des Lebens" is not proteid substance, but sugrar, or sugarproducing material. The discovery of this fundame:atal truth we owe first to bernard $(1 \$ 5 j-56)$, who brought to light the fact that such material plays an imp ortatit part in the nutrition of every living tissue: secondly, to looit (1S66). Who in elaburate experiments on cirnivorous animals, during periods of rest and cxertion, showed that, in comparing those conditions, no relution whatever shows itself between the quantity of proteid material (flesh) consumed, and the amount of work done; and finally to Frankland. Fick, and his associate llislicenus, as to the work-yielding value of different constituents of food, and ats to the actual expenditure of material in man during severe exertion. The sulpjects of experiment used by the two lest-mentimed phesiologiste were hemseless: the work done wits the mount rin ascent from lnterlalien to the summit of the fialhorn; the: result wiss a prove that the quantity of mitlerial used llats propertionil (1) th.: work done, and that that material Wis such as (1) yield water and carbonic acel exclusirely.

The investigators to whom I have just referred aime I at proving the correlation of prucess and presluct tor the whole animal crganism. The other mode of incuiry proposed by Maver, the veritication of his principle in respect of the work-doing mech mism-that is to saly, in respect of muscle taken separately- - has been pursued with equal perseverance during the last twenty gears, and with greater success; for in experimentines on a separate organ, which has no other functions escepting those which are in question, it is possible to eliminate uncertainties which are unavoidable when the conditions of the problem are more complicatted. Before 1 attempt to sketch the results of these experiments, 1 must ask your attention for a moment (1) the disceveries malle since Majer's epoch, concerning a clusely related subject, that of the Process of Respirition.

I wish that I had time to go back to the great discovery of Priestley (1776), that the essential facts in the process of respilation atre the giving olf of fived atr, as he called It, and the taking in of dephlogisticated air, and en relites to you the beatiful experiments by which he proved it ; and then to pass on to Lavoisicr (1777), who, on the other side of the Channel, made independently what was substantially the same discovery a litile after Priestley, and added others of even greater moment. According to Lavoisier, the chemical process of respiration is a slow combustion which has its seat in the lungs. At the time that Mayer wrote, this doctrinc still maintained its ascendency, although the investigntions of Matgnus $(1838$ ) had alrealy proved its fallacy. Mayer himself knew that the blocel possessed the pioperty of conveying oxygen from the lungs to the cappllaries, and of conveying carbonic acid gras from the ciplillatios to the lungs, which was sufficient to exclute the doctrine of Lavoisier. Our present knowledere of the su',ject was attained by two methods-viz., first, the investyration of the properties of the coloring mater of the biond, since called "harmoglobin." the intial step in which wats made by l'rof. Stoles in $1862:$ and secondly; the application of the mercurial air-pump as a means of cletermining the relations of oxygen and carbonic acid gats to the living blood and tissues. The last is a matter of such importance in relation to our subject that I shall ask your special attention to it. Suppose that I have a barometer of which the tube, instead of being of the ordinary form, is expanded at the top into a large bulb of one or two litres capacity, and that, by means of some stritible contrivance, I am able to introduce, in such a Wily at (1) hese: no time and to preclucle: the possibility of contatet with air. a fluid ounc: of blood from the artery of a living animal into the ricueus space-what would happ.n? Instantlp the glantity of blool woald be converled into froth. Which wisuld occupy the whole of the large bulb. The color of the froth would at first be scarlet, but would speedily change to crimson. It would soon subside, and we should then have the eavity which was before racusus occupied by the bloxi and its artses-namels, the overen, carbonic acid ras, and nitrogen previously contained in th. Ind if we had the me:ms (which acturily exist in the gas-pump) of separating the arowous miviture from the liguid, and of renewing the licuum, we should be able to determine 11) the total quantit; of atse's which the blood yieids, and $(2)$. by analysis, the proportion of each gas.

Now, with referenc: to the hlool, by the applic tion of the "bloot-punp," as it is called. we have learnel a are.tt many tacts relating to the nature of respiratim, particularly that the difference of venous arterial blood depends not on the presence of "effete matter." as used (1) be: thomght, but on the less amount of oxier n hell by its coloring matter, and hall the blond which ll mis back

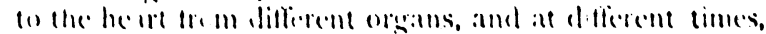

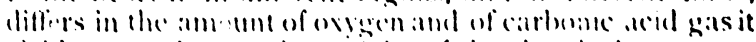
biekls, according to the activity of the chemicen precesses which have their seat in th. living tisstes trom which it flows.' liut this is not all that he hl od-pump has done for us. By applying it not merely to the blood, but to the tissues, we have latnel that the doctrine of Lavoisier wis wrong, not merely as regards the place, but as regarils the noture of the essential process in respiration. The fundaniental fact which is thus brought to light is this, that althourh livingr tissues are constantly and freely supplied with oxygen, and are in tact consiantly tearing it from the hiemoglobin which holds it. yet they themselves vield no oxigen to the vicuum. In other words, the oxigen which living protopl ism seizes upon with such enerisy that the bloced which thows by it is compeil-d to vield it up, becomes so entirely part of the living material itself that it cannot be se.burated even by the vacuum. It is in this way only that we can understand the secming paradox thit the oxygen, which is comveled in abuntance to every recess of our bodies by the blowel-stream, is nowhere to be found. Notwithstanding that noositlation-pruduct is formed, it becomes latent in every hit of living protonlasm: stored up in quant.ty proportional to its polential activity-i. c., to the work, intermal or external, it has to do.

Thus you see that the process of tissue respiration-in other words, the relation of living protoplasm to oxygenis very different from what Vityer, who localized oxidation in the captllaries, believed it to be. And this diff-rence has a scod deal to do with the relation of P'rocess (o) Product in muscle. Let us now revert to the experiments on this subject which we are to take as excmplitication of the truth of Matjer's forecasts.

If 1 only desired to convince you that during the last half-century there has been a greater accession of know. led a about the function of the living organism than cluring the previuus ore. I might armanire here a sinall heap at one ent of the table the physiologrical works of the II Inters. S-allanew i, Fontana, Inomas Young. li-nj: $m$ mon brolle, chates lied, and uthers, and then proceed to cover the rest at it with the recorts of origin al research on physiobscal subjects since is 31 . I sheulif tind that, even if I includeil only senume work, I should have to heap my table up on the ceilm:r. but I apprehend this would not give us a true answer to our quesion. Although, etymologic: Ily, seience and Kinowledgre me:an the same thing, their real meaning is different. B) science we mean, first of all, 
that knowledge which enables us to sort the things known according to their true relations. On this ground we call Haller the tather of physiology, because, regardless of existing theories, he brought together into a sy'stem all that was then known by olservation or experiment as to the processes of the living body. But in the "Elementa Physiologiate" we have rather that out of which science springs than science itself. Science can hardly be said 11) begin until we halve: by experiment acyuirid such a knowledge of the relation betieen events and their antecedents, between processes and their products, that in our own sphere we are able to forecast the operations of nature, even when they lie bejond the reach of direct observation. I would accordingly claim for physiology a place in the sisterhood of the sciences, not because so large a number of new facts have been brought to light, but because she has in her measure acquired that gift of prevision which has been long enjoyed by the higher branches of natural philosophy. In illustration of this I have endeavored to show you that every step of the laborious investigations undertaken during the last thirty years as to the process of nutrition, has been inspired by the provisions of J. R. Mayer, ancl that what we have learnt with so much labor by experiments on animals is but the realization of conceptions which existed two hundred years agro in the mind of Descartes as to the mechanisin of the nervous sistem. If I wanted another example I might find it in the provisions of Dr. Thomas Young as to the mechanism of the circulation, which for thirty years were utterly disregarded, until, at the epoch to which I have so often adverted, they received their full justification from the experimental investigations of Ludwig.

liut perhaps it will occur to some one that if physiology founds her claim to be regrarcled as a science on her power of anticipating the results of her own experiments, it is unnecessary to make experiments at all. $\mathrm{Al}$ though this objection has been frequently heard la'ely from certain persons who call themselves philosophers, it is not very likely to be made seriously here. The answer is, that it is contrary to experience. Nlthough we work in the certainty that every experimental result will come out in accordance with great principles (such as the principle that every plant or animal is both, as recrards form and function, the outcome of its past and present conditions, and that in every vital process the same relations obtain between expenditure and product as hold outside of the organism), these principles do little more for us than incicate the direction in which we are to proceed. The history of science teaches us that a gencral principle is like a ripe seed, which naty remain useless and inactive for an indefinite period, until the conditions favorable to its germination come into existence. Thus the conditions for which the theory of animal automatism of Descartes had to wait two centuries, were (1) the acquirement of an adequate knowledgre of the structure of the animal orsanism, and (2) the developinent of the sciences of phisies and chemistry: for at no earlier moment were these sciences competent to furnish eitluer the knowledere or the methods necessary for its experimental realization; and for a reason precisely siinilar Youngr's theory of the circulation was disto: garded for thirty years.

I trust that the example's I hatic placed before you today may hate been sufficient to show that the investigators who are now working with such earnestness in all parts of the world for the adrance of physiology, hate before them a definte and well-understood purpose, that purpose being to acquire an exact knowledge of the chemical and physical processes of animal life, and of the self-acting machinery by which they are regulated for the grencral good of the organism. The more singly and straightforwardly we direct our efforts to these ends, the sooner we shall attain to the still higher purpose-- the effectual application of our knowledge for the increase of human happiness.
The Science of Physiology has already afforded her aid to the $\Lambda$ rt of Medicine in furnishing her with a vast store of knowleclge obtained by the experimental investigation of the action of remedies and of the causes of diseases. These investigations are now being carried on in all parts of the world with great diligence, so that we may confidemily anticipalte that during the next generation the proyress of pathology will be as rapicl as that of physiology hats been in the pist. and thatl as time goes on the practice of medicine will grimluilly come more ind more moler the influence of scientific knowlenlye. That this change is alrealdy in progre'ss we halle abundant evidence. We need make no effori to hasten the process, for we may be quite sure that, as soon as science is competent to dictate, art will be reatly to obey.

\section{METEORIC IUUST.}

\section{BY P'rof. Schuster.}

A committee of the British Association was appointed for the double purpose of examining the observations hitherto recorded on the subject of meteoric dust and of discussing the possibility of future more systematic investigations. With regaril to the first point we note that in a paper presented to the Royal Astronomical Society in 1879, Mr. Ranyard has griven what appears to be a pretty complete account of the known observations as to the presence of meteoric dust in the atmosphere. It appears that in the year 1852 Prof. Andrews found native iron in the basalt of the Ciant's Causeway. Nordenskjöld found particles of iron which in all probability had a cosmic origin in the snows of Finland and in the icefields of the Arctic regions. 1)r. T L. Phipson, and more recently lissandier, found similar particles deposited by the winds on plates exposed in different localities. Finally, Mr. John dlurray discovered magnetic particles raised from deposits at the bottom of the sea by $\mathrm{H}$. II. S. Clacllensir. These articles were examined by Prof. Alexander llerschel, who arreed with Mr. Murray in ascribing a cosmic origin to them. For fuller details and all references we must refer to Mr. Ranyard's paper. There cannot be any duubt that magnetic dust, which in all probability derives it origin from meteors, has often been observed, and the question arises, in what way we can increase our knowledge on these points to an appreciable extent. A further series of occasional observations would in all probability lead to no result of great value, unless they were carried on for a great length of time in suitable places. Meteoric dust, we know, does fall, and observations ought if possible to be directed rather towards an approximate estimate of the quantity which falls within a given time. Difficulties very likely will be found in the determination of the locility in which the observations should be conducted. The place ought to be sheltered as much as possible against any ordinary dust not of meteoric origin. The lonely spots best fitted for these observations are generally accessible to occasional experiments only, and clo not lend themselves easily to a regular scries of observations. Nevertheless experiments continued for a few moriths at some elevited spot in the Alps might learl (o) valuable results. The Committec woulal like to draw attention to an instrunient which is well fittel for such olservations. It Was devised by Dr. l'ierre lliquel tor the purpose of examining. not the meteoric particles, but organic and organized matters floating abcut in the air. A description, with illustrations, will be found in the Innuaire de. Montsouris for 1879. Two forms of the instrument are given. In the first form, which is only adapted to permanent places of observations, an aspirator draws a quantity of air through a fine hole. The air impinges on a plate coated with glycerine, which retains all solid matter. By means of this instrument we may determine the quantity of solid particles within a given volume of air. 